\title{
Variability of Different Yield Contributing Parameters and Yield of Some Okra (Abelmoschus esculentus) Accessions
}

\author{
A. K. M. Ashraful Alam ${ }^{1 *}$ AND Md. Mokbul Hossain ${ }^{2}$ \\ ${ }^{1}$ Scool of Agriculture and Rural Development, Bangladesh Open University, Gazipur, Bangladesh \\ ${ }^{2}$ Banglasdesh Agricultural University, Mymensingh, Bangladesh
}

Received 24 May 2006; received in revised form 19 June 2006; accepted 22 June 2006

\begin{abstract}
In order to assess the variability of yield contributing characters of 50 okra accessions and their interrelation effects on the yield of green pod a field experiment was undertaken at the Horticulture Farm of Bangladesh Agricultural University, Mymensingh during the period from February, 2002 to May, 2002. A wide range of variation was observed incase of weight of green pod per plant (105281g), days to first flowering (40-52days) and weight of individual green pod (14-26g). Moderate variation for length of green pod (12-19cm), number of green pods per plant (6-11) and yield of green pod (4-13 t/ha), lesser variation for percent of dry matter content (5-8\%), number of ridges per green pod (5-9) and diameter of green pod (1-2cm) was observed. The highest genotypic coefficient of variation was observed incase of yield of green pod $(G C V=23.22 \%)$ followed by weight of green pod per plant (22.24\%), weight of individual green pod (18.68\%), number of ridges per green pod (13.49\%), number of green pod per plant (10.84\%), dry matter content of green pod (10.48\%), diameter of green pod (6.90\%) and length of green pod (6.24\%). These characters suggested the existence of justifiable genetic distance among different cultivars. Correlation coefficient indicated that yield of green pod had highly significant positive association with weight of green pod per plant and weight of individual green pod. Path coefficient analysis showed that the weight of green pod per plant and weight of individual green pod were directly contributed towards the yield of green pod.
\end{abstract}

Key words: Okra, accession, variability, yield.

\section{INTRODUCTION}

Okra (Abelmoschus esculentus L. Moench) is a popular vegetable crop which is widely grown throughout the tropics (Purseglove, 1968) and also well distributed in the Indian subcontinent and East Asia (Rashid, 1999). In Bangladesh, vegetable production is not uniform round the year. The production of vegetables are relatively in larger scale during the winter, but in lower scale during the summer. Of the total vegetable production, around 30\% is Rabi season (Anon., 1993). So okra can get an importance as a vegetable in summer. The average yield of okra in our country was $3.06 \mathrm{t} / \mathrm{ha}$ in 1999-2000 (BBS, 2000). The yield is very low compared to that of other developing countries, where the yield is as high as 7-12 t/ha (Yamaguchi, 1998). The yield of okra in Bangladesh is low particularly due to lack of high yielding varieties. For improving the production as well as yield of okra in the country, the "Conservation of Vegetable and Fruits in Bangladesh

\footnotetext{
* Corresponding author: Lecturer, SARD, BOU, Gazipur-1705. E-mail: akmaalam@yahoo.com

(C) 2006, School of Agriculture and Rural Development, Bangladesh Open University. All rights reserved.
} 
(CVFB)" project, has collected some okra accessions from different parts of Bangladesh and are being evaluated at the Department of Horticulture, Bangladesh Agricultural University, Mymensingh.

There is a need to intensify research efforts in several areas particularly the selection of superior genotypes. The basic key to bring about the genetic upgrading to a plant is to utilize the available or created genetic variability. If the variability in the population is largely due to genetic cause with least environmental effect, the probability of a superior genotype is much higher for the expression of desired characters. With this back ground information, the study was undertaken with the following objectives:

i) to assess the performance of okra accession for yield and yield contributing characters;

ii) to assess the variability for yield and yield contributing characters;

iii) to assess the interrelationships between yield and yield contributing characters.

\section{MATERIALS AND METHODS}

The experiment was conducted at the Horticulture Farm, Bangladesh Agricultural University, Mymensingh during the period from February to May, 2002. Fifty okra accessions were used in this study those were collected by the "Conservation of Vegetables and Fruits in Bangladesh (CVFB)" project from different parts of the country. These 50 accessions were considered as the treatments of the experiment and chosen primarily to represent the commercial types of okra grown in different parts of Bangladesh. The experiment was laid out in the Randomized Complete Block Design (RCBD) with three replications. One accession represented one treatment and seven plants in an accession represented one replication. The distance between replication to replication was $1 \mathrm{~m}$, plant to plant $45 \mathrm{~cm}$ and row to row $50 \mathrm{~cm}$. The experimental plots were properly prepared and added recommended doses of manures and fertilizers (Anon,1998). Other intercultural operations were done as and when necessary. Then green pods were harvested regularly when they attained edible stage. Harvesting was started from 18 April 2002 and was continued up to the last period.

Data on the 10 selected yield contributing characters such as days to first flowering, number of nodes at which first flower appeared, length of green pod, diameter of green pod, number of ridges per green pod, number of green pod per plant, weight of individual green pod, weight of green pod per plant, dry matter content of green pod and yield of green pod were recorded from the sample plants during the experiment. The data were analyzed using MSTAT-C and GENSTAT software to find out the significance of difference among the treatment means and genotypic coefficient of variation (GCV). The significance of the difference among the treatments means was evaluated by least significance difference (LSD) test for the interpretation of the results (Gomez and Gomez, 1984). Simple correlation coefficient ( $r$ ) among seven important characters of okra accessions was estimated accordance with the procedure followed by Singh and Chaudhury (1985). Path coefficient analysis was done according to the procedure employed by Dewey and Lu (1959) using simple correlation values.

\section{RESULTS AND DISCUSSION}

The study revealed that the days to first flowering varied significantly among the accessions and ranged from 40.33 to 52.75 days with the mean value of 44.27 days. The plant of accession number 69 showed the minimum days to first flowering (40.33) which was statistically similar with the accession 5, 12, 13, 18, 21, 25, 29, 30, 31, 34, 50, 52, 53, 55, 56, 57 58, 59, 60, 62, 63, 64, 65, $67,70,71,72,74$ and 77 (Table 1). The plant of accession number 7 showed the maximum days to first flowering (52.75) followed by accession number 54, 43 and 9 (48.27, 48.20 and 48.06, respectively). The days to first flowering as obtained in this study agrees with the findings of Singh et al. (1988) and Damarany and Farag (1994). There were considerable differences between genotypic (6.37) and phenotypic (12.25) variances as well as genotypic (5.70\%) and phenotypic (7.90\%) co-efficient of variation indicated considerable environmental effect upon the expression of the character of days to first flowering (Table 2). Dash and Mishra (1995) reported similar result in respect of days to first flowering. 
Table 1. Variability of different yield contributing characters of 50 okra accessions collected from different parts of Bangladesh

\begin{tabular}{|c|c|c|c|c|c|c|}
\hline Treatments & $\begin{array}{l}\text { Days to first } \\
\text { flowering }\end{array}$ & $\begin{array}{c}\text { No. of nodes at } \\
\text { which first flower } \\
\text { appeared }\end{array}$ & $\begin{array}{l}\text { Length of } \\
\text { green pod } \\
(\mathrm{cm})\end{array}$ & $\begin{array}{l}\text { Diameter of } \\
\text { green pod } \\
(\mathrm{cm})\end{array}$ & $\begin{array}{c}\text { No. of } \\
\text { ridges per } \\
\text { green pod }\end{array}$ & $\begin{array}{c}\text { Dry matter } \\
\text { content of } \\
\text { green pod (\%) }\end{array}$ \\
\hline $\begin{array}{l}\text { T1(A3) } \\
\text { T2(A5) }\end{array}$ & $\begin{array}{l}46.43 \\
43.33\end{array}$ & $\begin{array}{l}5.73 \\
6.27\end{array}$ & $\begin{array}{l}15.76 \\
14.83\end{array}$ & $\begin{array}{l}1.50 \\
1.53\end{array}$ & $\begin{array}{l}6.00 \\
5.00\end{array}$ & $\begin{array}{l}6.00 \\
5.70\end{array}$ \\
\hline T3(A7) & 52.75 & 7.13 & 13.66 & 1.33 & 5.00 & 4.90 \\
\hline T4(A8) & 45.13 & 6.00 & 13.00 & 1.43 & 6.00 & 6.00 \\
\hline T5(A9) & 48.06 & 7.06 & 12.67 & 1.26 & 7.00 & 5.50 \\
\hline $\mathrm{T} 6(\mathrm{~A} 11)$ & 47.33 & 6.06 & 13.67 & 1.20 & 5.00 & 5.50 \\
\hline T7(A12) & 41.80 & 5.00 & 15.33 & 1.37 & 7.00 & 5.30 \\
\hline T8(A13) & 41.67 & 4.73 & 16.00 & 1.76 & 6.00 & 6.10 \\
\hline T9(A14) & 47.28 & 6.06 & 15.66 & 1.60 & 6.00 & 5.40 \\
\hline T10(A18) & 42.60 & 4.73 & 13.33 & 1.47 & 8.00 & 5.30 \\
\hline $\mathrm{T} 11(\mathrm{~A} 19)$ & 46.27 & 6.80 & 11.50 & 1.13 & 7.00 & 6.20 \\
\hline $\mathrm{T} 12(\mathrm{~A} 21)$ & 43.13 & 6.26 & 14.66 & 1.36 & 5.00 & 7.00 \\
\hline T13(A25) & 43.40 & 5.20 & 13.16 & 1.23 & 6.00 & 5.90 \\
\hline T14(A28) & 44.73 & 5.93 & 13.83 & 1.53 & 6.00 & 6.00 \\
\hline T15(A29) & 42.60 & 4.67 & 15.00 & 1.43 & 5.00 & 5.80 \\
\hline T16(A30) & 43.53 & 4.80 & 15.50 & 1.70 & 5.00 & 5.20 \\
\hline T17(A31) & 42.87 & 4.73 & 14.66 & 1.73 & 8.00 & 6.20 \\
\hline T18(A32) & 46.13 & 6.33 & 14.33 & 1.40 & 6.00 & 5.33 \\
\hline T19(A34) & 41.60 & 5.06 & 14.33 & 1.46 & 5.00 & 6.50 \\
\hline T20(A35) & 46.46 & 5.73 & 14.33 & 1.40 & 6.00 & 6.70 \\
\hline T21(A36) & 46.00 & 6.26 & 14.00 & 1.70 & 9.00 & 6.60 \\
\hline T22(A38) & 45.20 & 6.50 & 15.34 & 1.63 & 6.00 & 5.50 \\
\hline T23(A39) & 45.13 & 5.80 & 17.33 & 1.77 & 6.00 & 6.73 \\
\hline T24(A43) & 48.20 & 4.67 & 14.66 & 1.47 & 8.00 & 7.40 \\
\hline T25(A44) & 47.93 & 6.80 & 16.67 & 1.50 & 5.00 & 6.20 \\
\hline T26(A48) & 46.53 & 6.33 & 16.67 & 1.53 & 5.00 & 6.80 \\
\hline T27(A50) & 42.40 & 5.14 & 16.16 & 1.53 & 6.00 & 5.70 \\
\hline T28(A52) & 43.40 & 6.26 & 15.33 & 1.43 & 6.00 & 6.30 \\
\hline T29(A53) & 41.87 & 5.20 & 14.65 & 1.50 & 6.00 & 6.00 \\
\hline T30(A54) & 48.27 & 6.20 & 14.65 & 1.33 & 5.00 & 5.80 \\
\hline T31(A55) & 42.23 & 4.73 & 17.00 & 1.70 & 7.00 & 7.90 \\
\hline T32(A56) & 43.00 & 4.47 & 17.00 & 1.56 & 7.00 & 5.70 \\
\hline T33(A57) & 43.26 & 4.67 & 17.66 & 1.70 & 5.00 & 5.73 \\
\hline T34(A58) & 42.33 & 4.87 & 14.67 & 1.53 & 5.00 & 7.00 \\
\hline T35(A59) & 41.93 & 5.60 & 14.34 & 1.40 & 6.00 & 5.70 \\
\hline T36(A60) & 41.60 & 5.40 & 13.33 & 1.53 & 5.00 & 7.16 \\
\hline T37(A61) & 46.47 & 5.93 & 16.00 & 1.50 & 6.00 & 5.80 \\
\hline T38(A62) & 41.53 & 4.46 & 18.00 & 1.80 & 6.00 & 5.56 \\
\hline T39(A63) & 42.20 & 4.90 & 15.33 & 1.50 & 6.00 & 7.33 \\
\hline T40(A64) & 43.47 & 5.00 & 17.00 & 1.70 & 6.00 & 6.20 \\
\hline T41(A65) & 41.20 & 4.40 & 18.66 & 1.87 & 5.00 & 6.70 \\
\hline T42(A66) & 44.86 & 5.86 & 16.33 & 1.34 & 5.00 & 5.90 \\
\hline T43(A67) & 42.46 & 5.67 & 18.66 & 1.56 & 7.00 & 6.13 \\
\hline T44(A69) & 40.33 & 4.33 & 19.16 & 1.83 & 5.00 & 5.46 \\
\hline T45(A70) & 43.13 & 5.06 & 16.00 & 1.60 & 7.00 & 7.56 \\
\hline T46(A71) & 40.73 & 4.87 & 17.66 & 1.63 & 6.00 & 6.33 \\
\hline T47(A72) & 43.47 & 5.06 & 17.00 & 1.33 & 6.00 & 7.43 \\
\hline $\mathrm{T} 48(\mathrm{~A} 74)$ & 43.06 & 5.13 & 11.66 & 1.67 & 7.00 & 6.30 \\
\hline T49(A75) & 44.73 & 6.40 & 16.00 & 1.56 & 6.00 & 5.63 \\
\hline T50(A77) & 42.93 & 5.60 & 13.66 & 1.37 & 6.00 & 5.30 \\
\hline $\operatorname{LSD}(0.05)$ & 3.93 & 0.57 & 3.91 & 0.37 & 1.43 & 1.00 \\
\hline Range & 40.33-52.75 & 4.33-7.13 & $11.50-19.16$ & $1.13-1.87$ & $5.00-9.00$ & $4.90-7.90$ \\
\hline Mean value & 44.27 & 5.52 & 15.23 & 1.51 & 6.02 & 6.13 \\
\hline
\end{tabular}


Number of node at which the first flower appeared varied significantly among the accessions and ranged from 4.33 to 7.13 with the mean value of 5.52. The accession number 69 had the minimum number of nodes at which first flower appeared which was statistically similar with the accession $13,18,29,30,31,43,55,56,57,58,62,63,65$, and 71 (Table 1). The highest number of node (7.13) was observed in the accession number 7 followed by accession number 9,19 and 44 (7.06, 6.80 and 6.80, respectively). Gondane and Bahatia (1995) observed similar result in respect of number of node at which first flower appeared. Little differences were found between genotypic (0.54) and phenotypic (0.66) variance as well as genotypic (13.29\%) and phenotypic $(14.76 \%)$ coefficient of variation indicated low environmental influence on this trait (Table 2). Sood et al. (1995) reported similar result in respect of number of node at which first flower appeared in okra.

Table 2. Genotypic variance, phenotypic variance, genotypic coefficient of variation, phenotypic coefficient of variation, range and mean of yield contributing parameters of $\mathbf{5 0}$ okra accessions

\begin{tabular}{|c|c|c|c|c|c|c|c|c|c|c|}
\hline Character & $\begin{array}{l}\text { Days to } \\
\text { first } \\
\text { flowering }\end{array}$ & $\begin{array}{c}\text { No. of } \\
\text { nodes at } \\
\text { which first } \\
\text { flower } \\
\text { appeared }\end{array}$ & $\begin{array}{l}\text { Length of } \\
\text { green } \\
\text { pod } \\
(\mathrm{cm})\end{array}$ & $\begin{array}{l}\text { Diameter } \\
\text { of green } \\
\text { pod } \\
(\mathrm{cm})\end{array}$ & $\begin{array}{l}\text { No. of } \\
\text { ridges } \\
\text { per } \\
\text { green } \\
\text { pod }\end{array}$ & $\begin{array}{c}\text { No. of } \\
\text { green } \\
\text { pod per } \\
\text { plant }\end{array}$ & $\begin{array}{l}\text { Weight of } \\
\text { individual } \\
\text { green } \\
\text { pod } \\
\text { (g) }\end{array}$ & $\begin{array}{l}\text { Weight of } \\
\text { green pod } \\
\text { per plant } \\
\text { (g) }\end{array}$ & $\begin{array}{c}\text { Dry } \\
\text { matter } \\
\text { content of } \\
\text { green pod } \\
(\%)\end{array}$ & $\begin{array}{c}\text { Yield of } \\
\text { green } \\
\text { pod } \\
\text { (t/ha) }\end{array}$ \\
\hline $\begin{array}{l}\text { Genotypic } \\
\text { variance }\end{array}$ & 6.37 & 0.54 & 0.90 & 0.01 & 0.66 & 0.97 & 13.07 & 1583.73 & 0.41 & 3.33 \\
\hline $\begin{array}{l}\text { Phenotypic } \\
\text { variance }\end{array}$ & 12.25 & 0.66 & 6.73 & 0.06 & 1.43 & 1.01 & 13.85 & 2734.82 & 0.63 & 4.53 \\
\hline $\begin{array}{l}\text { Genotypic } \\
\text { coefficient } \\
\text { of variation } \\
(\%)\end{array}$ & 5.70 & 13.29 & 6.24 & 6.90 & 13.49 & 10.84 & 18.68 & 22.24 & 10.48 & 23.22 \\
\hline $\begin{array}{l}\text { Phenotypic } \\
\text { coefficient } \\
\text { of variation } \\
\text { (\%) }\end{array}$ & 7.90 & 14.76 & 17.03 & 16.39 & 19.88 & 11.34 & 19.23 & 29.23 & 12.93 & 27.11 \\
\hline Range & $40.33-52.75$ & 4.33-7.13 & $11.50-19.16$ & $1.13-1.87$ & $5.00-9.00$ & $5.30-11.13$ & $14.00-25.66$ & $104.89-281.00$ & $4.90-7.90$ & $4.39-12.77$ \\
\hline Mean \pm SE & $44.27 \pm 0.81$ & $5.52 \pm 0.12$ & $15.23 \pm 0.80$ & $1.51 \pm 0.06$ & $6.02 \pm 0.72$ & $8.87 \pm 0.10$ & $19.35 \pm 0.29$ & $178.91 \pm 11.30$ & $6.13 \pm 0.30$ & $7.86 \pm 0.15$ \\
\hline
\end{tabular}

As regards length of green pod, it ranged from $11.50 \mathrm{~cm}$ to $19.16 \mathrm{~cm}$, significantly varied with the mean value of $15.23 \mathrm{~cm}$ among the studied accessions of okra. The maximum length of green pod $(19.16 \mathrm{~cm})$ was observed in the accession number 69 followed by accession number 67,65 and 62 $(18.66,18.66$ and $18.00 \mathrm{~cm}$, respectively) while the minimum length of green pod $(11.50 \mathrm{~cm})$ was recorded in the accession number 19 which was statistically similar with the accession 5, 7, 8, 9, $11,12,18,21,25,28,29,31,32,34,35,36,38,43,52,53,53,54,58,59,60,63,74$ and 77 (Table 1 and Plate 1). The result was obtained in this study on length of green pod supports the findings of Mishra et al. (1996) and Shridhar (1995). There were considerable differences between genotypic (0.90) and phenotypic (6.73) variances as well as genotypic (6.24\%) and phenotypic $(17.03 \%)$ co-efficient of variation indicated considerable environmental effect upon the expression of the character of pod length. Little differences were observed between genotypic $(11.55 \mathrm{~cm})$ and phenotypic $(12.61 \mathrm{~cm})$ variances as well as genotypic $(23.10 \%)$ and phenotypic $(24.13 \%)$ coefficient of variation indicating low environmental influence on this trait (Table 2). Dash and Mishra (1995) and Sood et al. (1995) observed similar genotypic coefficient of variance and Phenotypic coefficient of variance of length of pod.

In respect of diameter of green pod, significant variation was observed among the accessions. Maximum diameter of green pod $(1.87 \mathrm{~cm})$ was obtained from the accession number 65 followed by accession number 69 and $62(1.83$ and $1.80 \mathrm{~cm}$, respectively). On the other hand, minimum diameter of green pod $(1.13 \mathrm{~cm})$ was recorded from the accession number 19 which was statistically similar with the accession $3,7,8,9,11,12,18,21,25,29,32,34,35,43,44,52,53$, 
$54,61,63,66,72$ and 77 (Table 1). In this trait the mean value was $1.51 \mathrm{~cm}$. This finding was supported by Dash and Mishra (1995). However, considerable differences between phenotypic $(16.39 \%)$ and genotypic $(6.90 \%)$ co-efficient of variation indicated considerable environmental effect upon the expression of this character (Table 2). This finding was also supported by Dash and Mishra (1995).

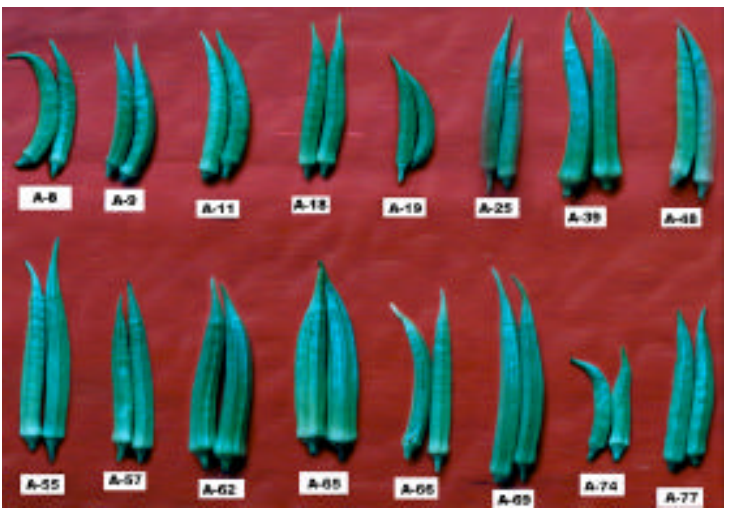

Plate 1. Photographic views represents the variability of green pod among the studied accessions of okra

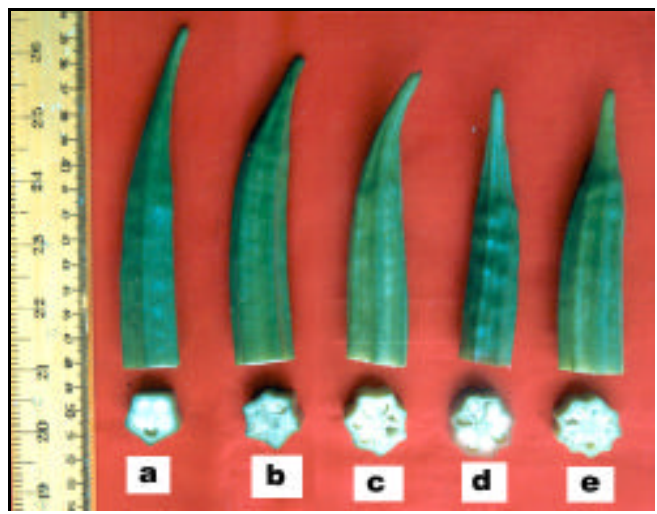

Plate 2. Photographic views represents the number of ridges per green pod among the studied accessions of okra and a, b, c, d, e shows 5, 6, 7, 8, 9 ridges, respectively.

Significant variation in respect of number of ridges per green pod was found. The number of ridges per green pod ranged from 5.00 to 9.00 with the mean value of 6.02 The accession number 36 produced highest number of ridges per green pod (9.00) followed by accession number 18, 31 and 43 produced the similar number of ridges per green pod which was 8.00 while accession number 5 , $7,11,21,29,30,34,44,48,54,57,58,60,65,66$ and 69 had the least number of ridges (5.00) per green pod which was statistically similar with the accession $3,8,13,25,28,32,35,38,39,50,52$, $53,59,61,63,66,72$ and 77 (Table 1 and Plate 2). It was supported by Kuwada (1964) and Mishra et al. (1996). Little differences were observed between phenotypic (1.43) and genotypic (0.66) variance as well as phenotypic (19.88\%) and genotypic (13.49\%) coefficient of variation indicating low environmental influence on this trait (Table 2). This result agrees with findings of Sood et al. (1995).

The number of green pods per plant varied significantly among the accessions and ranged from 5.30 to 11.13 . The plants of accession number 5 bore the minimum number of green pods (5.3) whereas accession number 65 bore the maximum number of green pods (11.13) followed by accession number 69 and 62 (10.95 and 10.89, respectively) (Fig. 1). It was supported by Shukla (1990) and Shridhar (1995). Slight differences were observed between genotypic (0.97) and phenotypic (1.01) variance as well as genotypic (10.84\%) and phenotypic (11.34\%) coefficient of variation indicating low environmental influence on this trait (Table 2). It was similar with the findings of Dash and Mishra (1995) and Singh et. al. (1998) observed genotypic coefficient of variation and phenotypic coefficient of variation on number of green pod per plant.

Weight of individual green pod varied significantly among the accessions and ranged from $14.00 \mathrm{~g}$ to $25.66 \mathrm{~g}$ (Table 1$)$. The pod of accession 69 was the heaviest $(25.66 \mathrm{~g})$ followed by accession 70 , 65 and $62(25.33,25.00$ and $25.00 \mathrm{~g}$, respectively). On the contrary, the lightest green pod $(14.00 \mathrm{~g})$ was observed with the accession 7, 29 and 50 that was similar with the accession 12, 59, 61 and 74 (Fig. 1). The similar findings also reported by Mishra et al. (1996). Little differences were observed between phenotypic (13.85) and genotypic (13.07) variance as well as phenotypic $(19.23 \%)$ and genotypic (18.68\%) coefficient of variation indicating low environmental influence on this trait (Table 2). It was supported by Lotilo (1989) who observed GCV and PCV on this trait. 


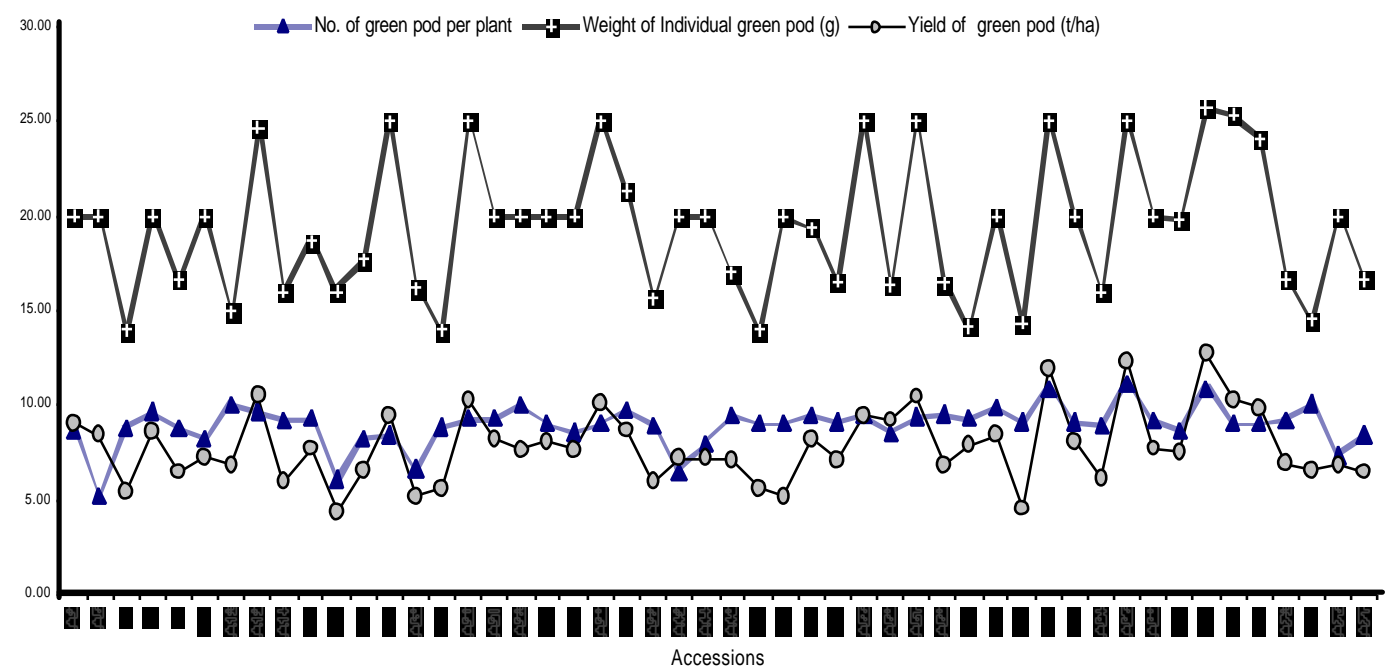

Fig. 1. Variability of no. of green pod per plant, weight of individual green pod and yield of green pod of 50 okra accessions

Weight of green pod per plant varied significantly ranging from $104.89 \mathrm{~g}$ to $281.00 \mathrm{~g}$ with the average value of $178.91 \mathrm{~g}$. The highest weight of green pod per plant $(281.00 \mathrm{~g})$ was found from the accession 69 followed rather closely by those of accession $65(278.33 \mathrm{~g}), 62(272.41 \mathrm{~g})$ whereas accession 61 was found to give the lowest weight of green pod per plant $(104.89 \mathrm{~g})$ which was statistically similar with the accession $7,9,11,12,14,19,21,28,29,39,50,52,58,64,72$, 72,75 and 77 (Fig. 2) This result was supported by Mishra et al. (1996) and Gondane and Bahatia (1995). However, considerable differences between genotypic (1583.73 g) and phenotypic $(2734.83 \mathrm{~g})$ variances as well as genotypic (22.24\%) and phenotypic (29.23\%) coefficient of variation indicated considerable environmental influence upon the expression of this character (Table 2). It was supported by Panda and Singh (1997).

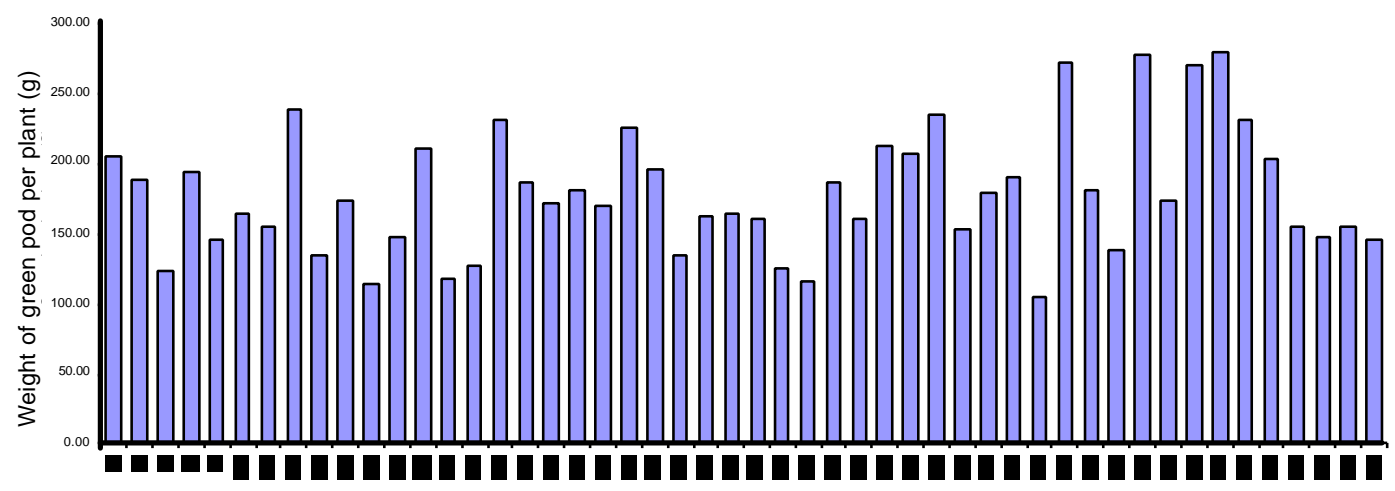

Fig. 2. Weight of green pod per plant (g) of 50 accessions of okra

In respect of dry matter content of green pod, remarkable variation was seen among the accessions. The highest dry matter content of green pod $(7.90 \%)$ was recorded in the accession 55 
followed by accession 70,72 and 63 (7.56\%, 7.43\% and 7.33\%, respectively). On the other hand, the lowest dry matter content of pod (4.90\%) was recorded in the accession 7 which was statistically similar with the accession $5,9,11,12,14,18,25,29,30,32,38,50,54,56,57,59,61$, 62, 66, 69, 75 and 77 (Table 1). In this trait the mean value was $6.12 \%$. Sistrunk et al. (1960) reported similar result in respect of dry matter content of green pod in okra. Slight differences were observed between genotypic (0.412) and phenotypic (0.628) variance as well as genotypic $(10.47 \%)$ and phenotypic $(12.93 \%)$ coefficient of variation indicated low environmental influence on this trait (Table 2). This result was agreed with the findings of Mishra et al. (1996).

Among the observed accessions, yield of green pod varied significantly and ranged from $4.39 \mathrm{t} / \mathrm{ha}$ to $12.77 \mathrm{t} / \mathrm{ha}$ with the average value of $7.85 \mathrm{t} / \mathrm{ha}$. The maximum yield of green pod (12.77 t/ha) was obtained in the accessions 69 and followed by accession 65, 62 and $13(12.32,11.93$ and 10.57 $\mathrm{t} / \mathrm{ha}$, respectively) whereas the minimum yield of green pod (4.39 t/ha) was obtained from accession number 19 which was statistically similar with the accession 7, 14, 28, 29, 39, 52, 61 and 64 (Fig. 1). This result agreed with the findings of Hussein et al. (1994) and Martin and Rhodes (1983). Considerable differences between genotypic (3.33 t/ha) and phenotypic $(4.53 \mathrm{t} / \mathrm{ha})$ variances as well as genotypic (23.22\%) and phenotypic (27.11\%) co-efficient of variation (Table 2$)$ indicating considerable environmental influence upon the expression of this character. It was supported by Singh et al. (1998).

\section{Correlation coefficient}

Estimation of simple correlation coefficient was made among five important yield components towards yield of the 50 okra accessions. The values of ' $r$ ' and the components correlated are presented in Table 3 . The result revealed that length of green pod had highly significant positively correlation with diameter of green pod $(r=0.851)$ and weight of individual green pod $(r=0.505)$. This indicates that diameter of green pod and weight of individual green pod will be increased with the increase of length of green pod. On the other hand this trait had negatively associated with the weight of green pod per plant (Table 3). This finding was supported by Shukla (1990).

It was noticed that diameter of green pod had highly significant and positive correlation with weight of individual green pod $(r=0.583)$ which indicate this trait will be increased with the increase of diameter of green pod. This character also positively associated with the weight of green pod per plant and yield of green pod (Table 3). Yadav and Dhankhar (2001) also reported similar result in okra.

Weight of individual green pod was significantly and positively correlated with the yield of green pod $(r=0.313)$, which indicate yield will be increased with the increase of weight of individual green pod (Table 3). The result of this study agrees with the findings of Dash and Mishra (1995).

Weight of green pod per plant had highly significant positive correlation with yield of green pod $(r=$ 0.629 ) which indicates that yield of green pod will be increased with the increase of weight of green pod per plant (Table 3). Similar findings were noticed by Hazra and Bashu (2000).

Table 3. Correlation coefficient between yield and yield contributing characters in 50 okra accessions

\begin{tabular}{lcccc}
\hline \multicolumn{1}{c}{ Traits } & $\begin{array}{c}\text { Diameter of } \\
\text { green pod }\end{array}$ & $\begin{array}{c}\text { Weight of individual } \\
\text { green pod }\end{array}$ & $\begin{array}{c}\text { Weight of green } \\
\text { pod per plant }\end{array}$ & $\begin{array}{c}\text { Yield of green } \\
\text { pod }\end{array}$ \\
\hline \hline Length of green pod & $0.851^{\star *}$ & $0.505^{\star *}$ & -0.025 & -0.020 \\
Diameter of green pod & & $0.583^{\star *}$ & 0.053 & 0.059 \\
Weight of individual green pod & & & $0.275^{\star *}$ & $0.313^{\star}$ \\
Weight of green pod per plant & & & & $0.629^{\star *}$ \\
\hline
\end{tabular}

Note: * indicate $5 \%$ level of significant (using mean values)

** indicate $1 \%$ level of significant (using mean values)

$\mathrm{df}=\mathrm{N}-2=50-2=48(5 \%=0.279,1 \%=0.361)$ 


\section{Path coefficient analysis}

Simple correlation values were used to compute the path analysis. Direct and indirect effects of different characters on yield of green pod have been presented in Table 4 . The result revealed that direct effect of length of green pod on yield of green pod was low and negative $(-0.181)$ whereas positive indirect effect of length of green pod on yield of green pod was contributed via diameter of green pod and weight of individual green pod.

Diameter of green pod showed very low direct and positive effect $(0.0756)$ on yield of green pod. This trait had also indirect positive effect on yield of green pod via weight of individual green pod and weight of green pod per plant (Table 4). Dash and Mishra (1995) reported similar result in okra.

Weight of individual green pod showed low direct positive effect $(0.228)$ on yield of green pod whereas indirect positive effect was contributed via diameter of green pod and weight of green pod per plant (Table 4). Dhall et al. (2000) reported similar result in respect of weight of individual pod.

Weight of green pod per plant showed medium direct effect $(0.474)$ on yield of green pod. This trait had also indirect positive effect on yield of green pod via length of green pod, diameter of green pod and weight of individual green pod (Table 4). The result of this study agreed with the finding of Dhall et al. (2000).

Table 4. Path analysis showing direct and indirect effects on yield components towards yield in $\mathbf{5 0}$ okra accessions

\begin{tabular}{lccccc}
\hline \multicolumn{1}{c}{ Traits } & $\begin{array}{c}\text { Length of } \\
\text { green pod }\end{array}$ & $\begin{array}{c}\text { Diameter of } \\
\text { green pod }\end{array}$ & $\begin{array}{c}\text { Weight of } \\
\text { individual } \\
\text { green pod }\end{array}$ & $\begin{array}{c}\text { Weight of } \\
\text { green pod } \\
\text { per plant }\end{array}$ & $\begin{array}{c}\text { Yield of } \\
\text { green pod }\end{array}$ \\
\hline \hline Length of green pod & $\underline{-0.181}$ & 0.064 & 0.115 & -0.0118 & -0.02 \\
Diameter of green pod & -0.154 & $\underline{0.07563}$ & 0.133 & 0.0251 & 0.059 \\
Weight of individual green pod & -0.091 & 0.044 & $\underline{0.228}$ & 0.130 & 0.313 \\
Weight of green pod per plant & 0.00452 & 0.0040 & 0.0628 & $\underline{0.474}$ & 0.629 \\
\hline
\end{tabular}

Note: Residual effect: 0.728

Underlined figures indicate the direct effects

The result of the study revealed that a wide variability exists among the collected okra accessions. These variabilities could be used for future breeding programme of okra in our country. Also there was association of different yield contributing characters with the yield of okra. Selection pressure should be applied to the desired characters such as node of first flowering, days to first flowering, number of green pod per plant, green pod weight etc. to develop a high yielding variety of okra. Further collection of okra germplasm should be continued for getting more variability and desired traits in okra germplasm.

\section{LITERATURE CITED}

Anonymous. 1993. Research and development of vegetables crops. Paper presented in the workshop on importance of okra as summer vegetable on 9-10 March 1993, IPSA, Gazipur. pp. 1-7.

Anonymous. 1998. A yellow vein mosaic disease resistant new variety of okra. A leaflet of BARI Dherosh-I, USAID/BARC/AVRDC/BARI, Joydebpur, Dhaka, Bangladesh.

BBS. 2000. Monthly Statistical Bulletin of Bangladesh (October). Bangladesh Bureau of Statistics, Ministry of Planning, Government of People s' Republic of Bangladesh, Dhaka. p. 55.

Damarany, A. M. and Farag, I. A. 1994. An evaluation of growth yield and quality of some okra cultivars and strains under Assiut condition. Assiut J Agril Sci 25(4), 57-70 [Cited from Hort Abstr 66(3), 284, 1996].

Dash, G. B. and Misra, P. K. 1995. Variation and character association of fruit yield and its component characters in okra (Abelmoschus esculentus L.). Current Agril Res 8(3\&4), 123-127 [Cited from Hort Abstr 66(11), 1198, 1996].

Dewey, D. K. and Lu, K. H. 1959. A correlation and path coefficient analysis of components of crested wheat grass and production. Agron J 51, 515-518. 
Dhall, R. K., Arora, S. K. and Rani, M. 2000. Correlation and path analysis in advanced generations of okra [Abelmoschus esculentus (L.) Moench.]. Indian J Hort 57(4), 342-346.

Gomez, K. A. and Gomez, A. A. 1984. Statistical Procedure for Agricultural Research. John Wiley and Sons. Inc. New York. pp. 67-215.

Gondane, S. U. and Bahatia, G. L. 1995. Response of okra genotypes to different environments. PKV Res J 19(2), 143-146.

Hazra, P. and Basu, D. 2000. Genetic variability, correlation and path analysis in okra. Ann Agril Res 21(3), 452-453.

Hussein, H. A., Farghali, M. A., El-zawahry, A. M. and Damarany, A. M. 1994. Growth, yield and nematode reaction in some okra accessions. Assiut J Agril Sci 25(3), 113-129 [Cited from Hort Abstr 66(1), 58, 1996].

Kuwada, H. 1964. Studies on varietal characters and their classification in okra (Abelmoschus esculentus). Tech Bull Fac Agril Kagawa 15, 79-88 [Cited from Hort Abstr 35(1), 122, 1965].

Lotilo, S. 1989. Assessing the viability of seeds of okra (Abelmoschus esculentus L) by biochemical assay. Cilture Protette 18(11), 93-94 [Cited from Hort Abstr 60 (6), 500, 1990].

Martin, F. W. and Rhodes, A. M. 1983. Seed characteristics of okra and related Abelmoschus species. Qualitas Plantarum Plant Food for Human Nutrition 33(1), 41-49 [Cited from Hort Abstr 54 (1), 19, 1984].

Mishra, S. N., Dash, S. N. and Mishra, D. 1996. Multivaried analysis of genetic divergence in okra (Hibiscus esculentus). Indian J Agril Sci 66(8), 502-503.

Panda, S. K. and Singh, P. K. 1997. Genetic variability and correlation between yield and yield component characters in okra (Abelmoschus esculentus (L.) Moench.). Indian J Agril Sci 63(10), 662-664.

Purseglove, J. W. 1968. Tropical Crops: Dicotyledons. Vol.2. $1^{\text {st }}$ Edition, John Wiley \& Sons Inc., New York. p. 370.

Rashid, M. M. 1999. Sabji Biggan (In Bengali). Rashid Publishing House, 94, Old DOHS, Dhaka-1206. p. 476.

Shridhar. 1995. Performance of okra varieties in South Andaman. Current Res 24(9), 169-171 [Cited from Hort Abstr 67(1) 48, 1997].

Shukla, A. K. 1990. Correlation and path coefficient analysis in okra. Prog Hort 22(1-4), 156-159.

Singh, A. K., Singh, K. P. and Singh, V. P. 1998. Genetic analysis of induced mutation of okra. Abelmoschus esculentus L. Veg Sci 25(2), 174-177.

Singh, R. K. and Chaudhury, B. D. 1985. Biometrical Methods of Quantitative Genetic Analysis. Harayana J Hort Sci 12(2), 151-156.

Sistrunk, W. A., Jones, L. G. and Miller, J. C. 1960. Okra pod growth habit. Proc. Amer Soc Hort Sci 76, 486491.

Sood, S., Arya, P. S. and Singh, Y. 1995. Genetic variability and correlation studies in okra Abelmoschus esculentus L. Adv Hort Forestry 4(4), 109-118.

Yadav, S. K. and Dhankhar, B. S. 2001. Correlation studies between various field parameters and seed quality traits in okra cv. Varsha Uphar. Seed Res 29(1), 84-88.

Yamaguchi, M. 1998. World Vegetables- Principles, Production and Nutritive Values. Van Nostrand Reinhold, New York. p.415. 